\title{
Editorial Child Abuse In Medical Practice
}

\author{
M Said Maani Takrouri
}

\section{Citation}

M Said Maani Takrouri. Editorial Child Abuse In Medical Practice. The Internet Journal of Health. 2006 Volume 6 Number 2.

\section{DOI: $\underline{10.5580 / 27 \mathrm{eb}}$}

\section{Abstract}

In this issue of The Internet Journal of Health an original paper comes from the Middle East about child abuse. [1] This is a very difficult subject to tackle in this journal. Knowing that such topic is ataboo topics in most society and in situation where are social disrfuption or war or social inrest this phenominon would take larger scale..

In starting with this topic in this journal we hope to expand awareness and data collections from all around the world to appear for best wellbeing of children of the world.

UNICEF uses the term 'child protection' to refer to preventing and responding to violence, exploitation and abuse against children and teens up to 18 yrs - including commercial sexual exploitation, trafficking, child labor and harmful traditional practices, such as female genital mutilation/cutting and child marriage. UNICEF's child protection programmes also target children who are uniquely vulnerable to these abuses, such as when living without parental care, in conflict with the law and in armed conflict. Violations of the child's right to protection take place in every country and are massive, under-recognized and underreported barriers to child survival and development, in addition to being human rights violations. Children subjected to violence, exploitation, abuse and neglect are at risk of death, poor physical and mental health, HIV/AIDS infection, educational problems, displacement, homelessness, vagrancy and poor parenting skills later in life.[3] Among many other programmes, UNICEF supports the international Child Rights Information Network. In 2007, UNICEF published An Overview of child well-being in rich countries, which showed the UK and the USA at the bottom of a league of 21 countries. [2]

Encyclopedic definition $\left.{ }_{3}\right]$ goes like this: Child abuse is defined as the physical, sexual, or emotional maltreatment or neglect of children by parents, guardians, or others. While most child abuse happens in the child's home, large numbers of cases of child abuse have been identified within some organizations involving children, such as churches, schools, child care businesses, and in particular native residential schools, $\left.{ }_{4}\right]$ or in government agencies. $\left.{ }_{5}\right]$ It also sometimes occurs almost anywhere (eg kidnappings, random murders etc.)

According to a recent UNICEF report on child well-being the United States and the United Kingdom ranked lowest among rich nations with respect to the well being of their children. This study also found that child neglect and child abuse are far more common in single-parent families than in families where both parents are present. There are many forms of abuse and neglect and many governments have developed their own legal definition of what constitutes child maltreatment for the purposes of removing a child and/or prosecuting a criminal charge. In the United States, the Federal Government puts out a full definition of child abuse and neglect and creates a summary of each State definition. $[2,5]$

The scope of child abuse is large and continuous in generating the necessary laws to prevent it or at least to create awarness for prevention.

Still the civilan disturbances, wars and lawlessness are the most evident nursing grounds for such evil phenomenon

\section{References}

1. Behshid Garrusi, Behshid Garrusi,, Behshid Garrusi .. Physicians' perception regarding Child maltreatment in Iran (IR)The Internet Journal of Health Vol. 6 Numbre 2: 2007 2. Children wellbeing http://www.unicef.org/media/files/ChildPovertyReport.pdf last accessed on October 25, 2007.

3. Child abuse .http://en.wikipedia.org/wiki/Child_abuse last accessed on October 25, 2007 
4. ^ Definitions of Child Abuse and Neglect: Summary of State Laws, that is part of the 2005 State Statute series by the Child Welfare Information Gateway.
5. Robinson . B.A (2001 October 25). Abuse at Canadian Native Residential Schools. ReligiousTolerance.org. Accessed 2007-09-13. 


\section{Author Information}

Mohamad Said Maani Takrouri, MB. ChB. FRCA (I)

Department of Anesthesia, King Fahed Medical City 